\title{
The nexus between corruption and capital account restrictions
}

\author{
Axel Dreher · Lars-H.R. Siemers
}

Received: 28 January 2008 / Accepted: 26 February 2009 / Published online: 14 March 2009

(c) The Author(s) 2009. This article is published with open access at Springerlink.com

\begin{abstract}
We provide a formal model illustrating the mutual relationship between corruption and capital account restrictions. Corrupt countries are more likely to impose capital controls because corruption reduces a government's ability to collect tax revenue. If controls exist, however, individuals try to mitigate the burden by offering bribes, thereby increasing corruption. We test the model using panel data for 80 countries over the period 1984-2002 and find that corruption and restrictions indeed affect each other. Government's attempts to increase revenue via controls on capital might thus invoke a restrictions-rent-seeking spiral with destructively high levels of both. Using capital controls to increase revenue should be reconsidered.
\end{abstract}

Keywords Corruption $\cdot$ Capital account restrictions $\cdot$ Rent-seeking $\cdot$ Tax avoidance $\cdot$ Tax evasion

JEL Classification C33 $\cdot \mathrm{D} 19 \cdot \mathrm{F} 33 \cdot \mathrm{G} 11 \cdot \mathrm{H} 26 \cdot \mathrm{O} 17$

A. Dreher $(\bowtie)$

Georg-August University Goettingen, Platz der Goettinger Sieben 3, 37073 Goettingen, Germany

e-mail: mail@axel-dreher.de

A. Dreher

KOF Swiss Economic Institute, Zurich, Switzerland

A. Dreher

IZA, Bonn, Germany

A. Dreher

CESifo, Munich, Germany

L.-H.R. Siemers

Department of Public Finance, RWI Essen-Institute for Economic Research, Hohenzollernstraße 1-3, 45128 Essen, Germany

e-mail: siemers@rwi-essen.de 


\section{Introduction}

According to the World Bank (2008), corruption is "among the greatest obstacles to economic and social development." The World Bank estimates that more than US \$1 trillion is paid in bribes each year (World Bank Institute 2007; Eigen 2008). As corruption thus represents one of the major "taxes" on economic agents it has won increasing interest in the economics literature. ${ }^{1}$ Capital controls, in turn, are also widespread across the world, especially in Sub-Saharan Africa (Asiedu and Lien 2003). Their major purpose is to increase tax revenue and to reduce the danger of financial and bank crises (Milesi-Ferretti 1998). In addition, some institutions and politicians favour such controls to stem the effects of globalization.

The relationship between corruption and capital flows has frequently been investigated without, however, providing consistent results. While some studies show that corruption reduces capital imports (Smarzynska and Wei 2000; Wei 2000; Drabek and Payne 2001), others do not find any significant correlation (Wheeler and Mody 1992; Alesina and Weder 2002). ${ }^{2}$ As Bai and Wei (2001) argue, more corrupt countries are more likely to impose capital controls because corruption reduces a government's ability to collect tax revenue. According to Edwards (1999), DeLong and Eichengreen (2002), and El-Shagi (2005a, 2005b, 2006, 2007), however, capital controls may breed corruption. If controls exist, individuals try to mitigate the burden by offering side payments and bribes. ${ }^{3}$ Shleifer and Vishny (1993) emphasize that the imposition of capital controls creates a bottleneck that investors have to pass, thereby easing the collection of bribes (rent-seeking). ${ }^{4}$ Combining the two lines of argumentation, we hypothesize a mutual relationship between corruption and capital account restrictions.

We demonstrate how such a mutual relationship may develop in a formal model and confront our hypotheses with data. In our framework, capital account restrictions are used by governments to increase tax revenue: restrictions reduce foreign investments by inlanders, which are difficult to observe for the government. Hence domestic investments, which are easier to observe, increase, and the government's tax revenue rises. However, suchlike restrictions cause corruption, since they reduce the net benefits of investors and so create an incentive to circumvent these restrictions by engaging in bribery. Moreover, given the restrictions and the demand of investors to avoid them, bureaucrats have an incentive to arrange for hidden payments for reducing the burden of controls on investors. Then, in turn, the government is forced to tighten capital account restrictions, which might imply destructive competition between the government and investors. Hence, we follow a public choice perspective where corruption is a consequence of rational behavior of primarily self-

\footnotetext{
${ }^{1}$ Dreher and Herzfeld (2008) provide a recent survey. See also Jain (2001).

${ }^{2}$ Aidt and Gassebner (2007) show that such a relationship also extends to international trade as they identify red-tape and corruption as one reason why autocratic regimes trade less compared to democracies.

${ }^{3}$ To some extent, corruption might thus be efficient. However, Wei (2000) finds no evidence for the "efficient grease hypothesis," and Méon and Sekkat (2005) rather find some evidence that corruption sands the wheels of the system. According to Dreher et al. (2007), the losses in per capita GDP due to corruption are substantial. To the contrary, Méon and Weill (2006) show that corruption indeed reduces aggregate efficiency in countries where institutions are effective, but increases efficiency when institutions are ineffective. Dreher and Gassebner (2007) also find that corruption greases the wheels.

${ }^{4}$ Lambsdorff (2006, p. 32) and Jain (2001, pp. 93-94) show that rent-seeking behavior in order to attain bribes may lead to overinvestment in areas where the opportunities to arrange for hidden payments are better and to underinvestment in areas where these opportunities are weaker.
} 
interested individuals in a given system of incentives (Shughart 2006). ${ }^{5}$ Confronting our hypotheses with data, we find evidence that corruption and capital account restrictions are indeed mutually determined.

This bears important policy implications. Clearly, advantages and drawbacks of controls have to be carefully considered. They hold the risk of a destructive "capital account restrictions-corruption spiral." 6

We proceed as follows. The next section presents the formal model, while Sect. 3 describes our method and data. Results are shown in Sect. 4; the final section concludes.

\section{Formal model}

Consider a small open economy populated by a continuum of homogenous households. The representative household is endowed with wealth normalized to unity. It maximizes capital income by investing domestically and abroad. The domestic rate of return is given by $r$ and the rate abroad by $r^{*}$. The fraction of wealth invested at home is denoted by $d$ and the fraction invested abroad by $d^{*}$.

The government finances its planned expenditures of size $E$ by capital income taxes. Let $t$ denote the tax rate per unit of capital earnings. For simplicity, we assume that capital income earned abroad cannot be observed ${ }^{7}$ and hence that none of it is reported to the tax office. It follows that the household prefers investing abroad, so that the government does not generate sufficient revenue to finance $E$. Therefore, the government introduces a capital account restriction $c$ to reduce tax evasion. ${ }^{8}$ In general, there are two types of capital controls: (i) controls that levy an extra cost on foreign investment and function as a tax on investments abroad, that is, they lower the rate of net return on foreign investment, for instance, due to discriminating exchange rates (indirect capital controls): $r^{*}=r^{*}(c)$ with $\partial r^{*}(c) / \partial c<0$; (ii) controls that function as quotas and restrict the amount of wealth allowed to be invested abroad (direct capital controls): $d^{*} \leq \bar{d}^{*}(c)$ with $\partial \bar{d}^{*}(c) / \partial c<0$. Both tools decrease the incentive for investing abroad and thus increase the incentive to invest at home: $d=d(c)$ with $\partial d(c) / \partial c>0$. The government chooses the level of control $c$ such that the tax revenue suffices to finance state expenditures $E:^{9}$

$$
t \cdot d(c) \cdot r=E
$$

\footnotetext{
${ }^{5}$ For a recent treatment of the relevance of the rational choice approach see the special Public Choice issue on terrorism (Vol. 128, pp. 1-2, 2006), and in particular Rowley (2006).

${ }^{6}$ See also the vicious-circle argumentation in Krueger $(1974,1993)$.

${ }^{7}$ Burgess and Stern (1993) report that capital gains earned abroad are difficult for the tax institutions to observe.

${ }^{8}$ Using capital controls to solve the problem that taxing foreign income is infeasible has been, for instance, proposed by Eaton (1987). As we do, he emphasizes that this benefit needs to be weighed against social costs like the rent-seeking activity that these controls impose. In reality, capital controls may also be perceived as unfair, and might thus reduce tax compliance (Hasseldine and Bebbington 1991).

${ }^{9}$ Arguably, capital controls are sometimes also used to increase the independence of monetary policy, to promote foreign currency reserves, to protect undeveloped markets and infant industries from foreign competition, or to stem capital outflows to reduce the risk of international financial crises (Stockman and Hernandez 1988; Milesi-Ferretti 1998; Neely 1999; Alfaro 2001). However, a major motivation for introducing capital account restrictions is to stem capital flight that is undertaken to avoid or evade capital income taxes, as in our model, since capital gains abroad can hardly be monitored (Burgess and Stern 1993; Bartolini and Drazen 1997; Bai and Wei 2001). There is a trade-off between increasing tax rate $t$ on the one hand and stricter controls on the other. Whereas stricter controls increase corruption, higher taxes increase the stimulus for tax evasion and avoidance. Hence the tax effect is an alternative variety of the same story. We abstract from this complication for reasons of simplicity.
} 
However, given the capital control, the representative investor has an incentive to circumvent it by bribing the government officials who monitor the capital account restrictions. Bureaucrats, in turn, attempt to increase their level of compensation by accepting bribes, so that there is bureaucratic corruption (Büchner et al. 2008; Mbaku 1991, 1996). That is, bureaucrats behave self-interestedly and adapt to the change of incentives induced by the introduction of the capital account restriction. ${ }^{10}$ We assume that when there are indirect capital controls, the net return on foreign investment can be increased by bribing officials, and when there are direct capital controls, bribery allows augmenting foreign investment. If we denote the amount of wealth used for bribery by $b>0$, we thus obtain: ${ }^{11} \partial r^{*}(c, b) / \partial b>0$ and $\partial \bar{d}^{*}(c, b) / \partial b>0$. In the case of indirect controls (type (i)), the representative household solves

$$
\max _{\left\{d, d^{*}, b\right\}} d \cdot(1-t) r+d^{*} \cdot r^{*}(c, b) \quad \text { s.t. } \quad d+d^{*}+b \leq 1 \quad \text { and } \quad d, d^{*}, b \geq 0,
$$

and in the case of direct controls (type (ii)),

$$
\max _{\left\{d, d^{*}, b\right\}} d \cdot(1-t) r+d^{*} \cdot r^{*} \quad \text { s.t. } \quad d+d^{*}+b \leq 1, \quad d^{*} \leq \bar{d}^{*}(b) \quad \text { and } \quad d, d^{*}, b \geq 0 .
$$

Hence, there are three representative agents - the government, its official, and an investor. We assume that the official is corrupt, ${ }^{12}$ but that the government is not. That is, capital controls are solely introduced for ensuring the financing of state expenditures.

This approach abstracts from other rent-seeking behavior of bureaucrats, politicians and other interest groups (e.g., Stigler 1971; Krueger 1974; Posner 1974; Peltzman 1976; Bhagwati 1982; Becker 1983; Mbaku 1991, 1996; Shleifer and Vishny 1993; Duso 2005). Lobby groups try to distort governments' decisions to attract rents, and Lambsdorff (2002, p. 98) emphasizes that there is no reason to believe that governments themselves are immune to corruption. This strand of literature highlights that institutions like taxes or tariffs are not created to be socially efficient, but serve the interests of those with the bargaining power to create them (North 1994, p. 360). In such an alternative setting the appearance of corruption would be volitional, in order to generate private earnings. To focus on the reciprocity of corruption and controls we abstract from this complication. This guarantees that the model remains tractable and illustrates the major mechanisms of transmission between corruption and capital account restrictions. In the empirical analysis and in the conclusion we will discuss the effects of additional rent-seeking behavior.

In scenario (i), arbitrage equilibrium demands that the net rates of return on investment abroad and at home are equalized. The world market rate of return, labelled $\bar{r}^{*}$, cannot be influenced by the small economy, but the capital control reduces the net return of inlanders and corruption increases this rate. Thus, the equilibrium level of domestic investment, denoted by $d^{\text {eq }}$, is determined by condition $(1-t) r=r^{*}(c, b)$ and the equilibrium level of

\footnotetext{
${ }^{10}$ This follows the tradition of public choice by dropping the implicit orthodox faith in benevolent bureaucrats (Shughart and Tollison 2005). We apply the rational-actor model of economics to a problem of bureaucracy.

${ }^{11}$ We do not model the fact that the bribee and the investor bargain about the size of the bribe. In our model, there is implicitly a one-off fixed price demanded by the official that is exogenous for the investor. This keeps the model tractable. An analysis of the bargaining about the size of the bribe can be found in Büchner et al. (2008), Rose-Ackerman (1997), or Shleifer and Vishny (1993). We also abstract from including the use of the bribe earnings of the officials, since this has no relevant effect on our investigation.

${ }^{12}$ Mbaku (1991) has shown that bureaucratic corruption significantly increases the public employee's total compensation in Africa.
} 
corruption, $b^{\text {eq }}$, by $d^{* \text { eq }} \cdot \partial r^{*}\left(c, b^{\text {eq }}\right) / \partial b=(1-t) r$. The left-hand side of the last equation represents the marginal benefit from bribing officials and thus is the marginal willingness to pay bribes, determined mainly by the effectiveness of bribing, given by derivative $\partial r^{*}\left(c, b^{\text {eq }}\right) / \partial b$. At the optimum, the willingness to pay bribes must be equal to $(1-t) r$, which represents the marginal cost of paying one unit of bribe, where these marginal costs decrease with the tax rate on capital gains. Overall, we obtain $b^{\mathrm{eq}}=b(c)$ with $\partial b^{\mathrm{eq}} / \partial c \geq 0$.

If, alternatively, the capital control is of type (ii), household optimum is described by $\left[\bar{r}^{*}-(1-t) r\right] \cdot \frac{\partial \bar{d}^{*}\left(b^{\mathrm{eq}}\right)}{\partial b}=(1-t) r, d^{* \text { eq }}=\bar{d}^{*}\left(b^{\mathrm{eq}}\right)$ and $d^{\mathrm{eq}}=1-\bar{d}^{*}\left(b^{\mathrm{eq}}\right)-b^{\mathrm{eq}}$, where the left-hand side of the first term again determines the marginal willingness to pay bribes, given by the marginal benefit of bribing, and the right-hand side of the first term again represents the marginal cost of bribing. Therefore, the marginal willingness to bribe is determined by the net interest rate differential and by the effectiveness of bribing, given by derivative $\partial \bar{d}^{*}\left(b^{\text {eq }}\right) / \partial b$. Note that in case (ii) we have $d c=-d \bar{d}^{*}$. Hence, we conclude $b^{\text {eq }}=b(c)$ with $\partial b^{\text {eq }} / \partial c \geq 0$.

Turning to the government's behavior, we supplement corruption to objective function (1) and arrive at:

$$
t \cdot d(c, b) \cdot r=E .
$$

The government takes into account that $\partial d(c, b) / \partial c>0$ and $\partial d(c, b) / \partial b<0$. It follows that the required level of control is an increasing function of the degree of bribery: ${ }^{13} c^{\mathrm{eq}}=c(b)$ with $\partial c(\cdot) / \partial b>0$.

The investor and the government therefore play a Cournot game, with $b(c)$ and $c(b)$ representing the reaction functions of the investor and of the government, respectively. The Nash equilibrium is deduced by equating the two reaction functions $b(c)$ and $c^{-1}(b){ }^{14}$

In order to compute the equilibrium we specify $r^{*}(c, b) \equiv \bar{r}^{*}-\alpha \cdot c+\beta \cdot b$ and focus on the more realistic type (i). Applying first-order condition $(1-t) r=\bar{r}^{*}-\alpha \cdot c+\beta \cdot b$ we find $b(c)=\frac{\alpha \cdot c-\left[r^{*}-(1-t) r\right]}{\beta}$. That is, corruption increases with a stricter capital control and with an increasing effectiveness of controls $(\alpha)$, and decreases with increasing effectiveness of bribing $(\beta)$ and with the net interest differential in general equilibrium. ${ }^{15}$ We thus obtain:

\section{Proposition 1 Capital account restrictions promote corruption:}

$$
\frac{\partial b(c)}{\partial c} \geq 0
$$

If we now use first-order condition $d^{*} \cdot \beta=\bar{r}^{*}-\alpha \cdot c+\beta \cdot b$, we obtain $d^{*}(b, c)=$ $\frac{1}{\beta}\left(\bar{r}^{*}+\beta \cdot b-\alpha \cdot c\right)$. Setting $d^{*}(b, c)$ and $b(c)$ into $E=t \cdot r \cdot\left(1-d^{*}-b\right)$, we find the reaction function of the government: $c(b)=\frac{1}{\alpha}\left[\bar{r}^{*}+\beta \cdot\left(\frac{E}{t \cdot r}+2 \cdot b-1\right)\right]$. We see that the restriction becomes stricter when the level or the effectiveness of corruption increases. We thus infer:

\footnotetext{
${ }^{13}$ There is also evidence that more corrupt states in the United States have lower bond ratings, and hence may pay higher interest on public debt (Depken and Lafountain, 2006).

${ }^{14}$ If we assume that the government is a dominant player that moves first, the investor and the government play a von Stackelberg game. Then equilibrium is found by determining that point at the reaction function of the representative investor which generates the highest value of the government's objective function. In our model this is equivalent to the Cournot outcome.

${ }^{15}$ Given a diminishing-rate-of-return technology, the excess supply of capital caused by the capital account restriction decreases the domestic net rate of return.
} 
Proposition 2 Corruption leads to stricter capital account restrictions:

$$
\frac{\partial c(b)}{\partial b}>0 .
$$

Equalizing the two reaction functions, we obtain:

Proposition 3 The unique Cournot-Nash-Equilibrium of the government-investor game is given by:

$$
\left(b^{\text {Cournot }}, c^{\text {Cournot }}\right)=\left(1-\frac{E}{r \cdot t}-\frac{(1-t) \cdot r}{\beta}, \frac{\beta\left(1-\frac{E}{t \cdot r}\right)-2(1-t) r+\bar{r}^{*}}{\alpha}\right) .
$$

Though our model is stylized, the result of a reinforcing corruption-restrictions link is an important aspect for economic policies building on the usage of capital account restrictions. The reinforcing relationship holds analogously if the government increases the tax rate instead of tightening capital controls: higher tax rates increase the stimulus for tax evasion and avoidance; if public servants collude with taxpayers, this will also involve increased corruption. ${ }^{16}$ Alternatively, the government could intensify the fight against corruption. However, Friehe (2008) shows that harsher anti-corruption measures may increase the incentives to engage in crime. Hence, even anti-corruption strategies may, to some extent, generate deadweight losses. ${ }^{17}$

The conclusion from Propositions 1 to 3 , to be inspected empirically, is the following:

Proposition 4 Capital account restrictions and corruption determine each other mutually.

\section{Data and econometric approach}

In the following we empirically test for the relationship between corruption and capital account restrictions predicted by our theoretical model.

To measure corruption, we employ an index of perceived corruption provided by the International Country Risk Guide. This indicator is based on the analysis of a world-wide network of experts. It is well suited to test the predictions of our model. ${ }^{18}$ The index is ordinal and ranges from $0-6$. We rescaled the original index, so that higher values represent more corruption.

Our indicator of capital account restrictions is constructed with binary data from the International Monetary Fund's annual report Exchange Arrangements and Exchange Restrictions. The IMF data are the most widely used measures of capital controls and allow

\footnotetext{
${ }^{16}$ Roine (2006) shows that tax avoidance does not necessarily lead to higher official tax rates in political equilibrium. If the tax avoidance technology is effective, however, it is even possible that a coalition of poor and the very richest favour a higher tax rate in equilibrium.

${ }^{17}$ Nonetheless fighting corruption is an important building block of a good development strategy. Analyses of fighting corruption could be found, for instance, in Mbaku (1996) or Boehm (2007). See also Lambsdorff (2007). See Nell and Lambsdorff (2007) for an interesting proposal designing asymmetric penalties and leniency among bribe takers and givers.

${ }^{18}$ Note that the focus of this index is on capturing political risk involved in corruption. Since it is the only perception-based data on corruption providing consistent time series, the index has been widely used in empirical studies. Dreher et al. (2007) provide an alternative index which is partly based on hard data. However, the data are not available for most of the years we cover here, so we do not use it.
} 
an almost universal coverage of countries. We focus on four forms of restrictions to measure the set of capital controls: (i) restrictions on payments for capital account transactions, (ii) separate exchange rate(s) for some or all capital transactions and/or some or all invisibles, and (iii) surrender requirements for proceeds from exports, invisible transactions, or both; since current transactions can be used to circumvent restrictions on the capital account (Milesi-Ferretti 1998, p. 225), ${ }^{19}$ we also include (iv) restrictions for payments on current transactions. We apply an index of restrictions that aggregates the four measures. The index takes the value of four for fully restricted capital accounts, and zero, if no restrictions are in place. ${ }^{20}$ As an obvious shortcoming of this approach, our index neither measures the intensity nor the effectiveness of controls. One would also like to distinguish between controls on inflows of capital and those on outflows. We do, however, neither have the data to adequately control for intensity and effectiveness, ${ }^{21}$ nor those for an analysis of inflows and outflows.

To assess the relationship between corruption and restrictions, we use a panel of 80 low and middle income countries (listed in Appendix C). ${ }^{22}$ Our data cover the years 1984-2002. We employ averages over three years for all variables. This makes the indices of corruption and capital account restrictions continuous with values ranging between zero (no corruption) and six (high corruption) and, respectively, zero (not restricted) and four (fully restricted). By making the dependent variables less discrete, we can use linear estimation methods. ${ }^{23}$ Some of the data are not available for all countries or every year. Therefore, our panel data are unbalanced and the number of observations depends on the choice of explanatory variables. All variables, their precise definitions and data sources are listed in Appendix A, while Appendix B provides summary statistics.

Column 1 of Table 1 shows the estimates of the effect of capital account restrictions on corruption, estimated with OLS. To account for time-invariant unobservable heterogeneity potentially correlated with the regressor, we use a fixed effects specification (which is clearly favored over random effects by the Hausman test). Therefore, we could not include variables that do not change over time. ${ }^{24}$ We also tested for fixed time effects but found them to be insignificant.

Following Lederman et al. (2001), we tested for the influence of four groups of control variables broadly relating to the political system, cultural factors, government policies, and a country's degree of development. ${ }^{25}$ We started by including the groups of variables one at a time in addition to the index of capital account restrictions. In column (1), we include all

\footnotetext{
${ }^{19}$ In 1997, the IMF changed the format of its survey. Following Glick and Hutchison (2005) we coded "restrictions on payments for capital account transactions" to be unity if controls were in place in 5 or more of the sub-categories of capital account restrictions, and "financial credit" was one of the categories restricted.

${ }^{20}$ A similar procedure has been employed, e.g., by Gruben and McLeod (2001) and Bai and Wei (2001).

${ }^{21}$ To proxy the intensity or effectiveness of capital controls, black market premiums, onshore-offshore interest rate differentials and deviations from covered interest parity have been employed (cf., e.g., Dooley and Isard 1980; Giavazzi and Pagano 1988). However, those variables measure other aspects as well.

${ }^{22}$ According to the recent analysis of Weber Abramo (2008) pooling industrialized and developing countries, when analyzing corruption, is clearly inadequate. We therefore exclude high income countries according to the definition of the World Bank (2006), i.e., countries in which 2004 gross national income per capita was US $\$ 10,066$ or more.

${ }^{23}$ Given the bounded nature of our variables of interest, we replicate the analysis with Tobit. As described below, the main results are unchanged.

${ }^{24}$ Like dummies for developing countries, for example, or institutional measures that have been shown to affect economic performance (Knack and Keefer 1995).

${ }^{25}$ We employed the following variables: (i) an index for the competitiveness of nominating candidates for the legislature, indices measuring legislature fractionalization of the government and, respectively, the opposition,
} 
Table 1 Corruption and capital account restrictions (panel data, 80 countries, 1984-2002, OLS, fixed effects)
(1)

$\begin{array}{ll}\text { Capital account restrictions } & 0.111 \\ & (2.42)^{* *} \\ \text { Index of democracy } & -0.071 \\ & (4.27)^{* * *}\end{array}$

Corruption

Left governments, dummy

$\ln ($ gdp per capita)

$\ln$ (population)

$(4.97)^{* * *}$

Openness

Monetary growth 0.0002

Gross domestic savings

gdp growth

Constant

$-2.832$

$(19.62)^{* * *}$

Observations

425

405

Number of countries

80

78

R-squared
0.24

All variables are averages over three years

variables that have been significant at the $10 \%$ level at least according to these preliminary specifications.

As can be seen, the only significant covariate is democracy, which reduces corruption at the $1 \%$ level of significance. ${ }^{26}$ The positive impact of democracy is in line with several studies surveyed in Lambdsdorff (2006, pp. 10-17). If corruption is high, the government will be punished in the next election, so that political competition decreases the level of corruption in democracies (Schumpeter 1942; Rose-Ackerman 1978, p. 281). In line with our finding, Gerring and Thacker (2004) and Treisman (2000) provide evidence that democracy significantly reduces corruption. ${ }^{27}$

a dummy which takes the value one if the IMF classifies the exchange rate of the respective country as fixed, and zero otherwise, (ii) the share of Protestants in the population, as other cultural variables available do not vary over time, (iii) total government revenue/spending as a share of GDP, a country's exports and imports relative to GDP, and (iv) GDP per capita and rates of illiteracy.

${ }^{26}$ Goel and Nelson (1998) show that government size has a strong positive effect on corruption in the U.S. However, in our panel, we do not find evidence for this channel. We also do not find evidence that economic openness decreases corruption (as do Ades and di Tella 1999).

${ }^{27}$ As Rose-Ackerman (1999) emphasizes, serious imbalances in political power can foster corruption. Hence, established democracies have lower levels of corruption. See also Jain (2001, pp. 82-83). Karahan et al.'s 
Turning to the impact of capital account restrictions, column (1) also shows that corruption indeed increases with restrictions, at the 5\% level of significance (in line with Proposition 1). The coefficient is quantitatively relevant. A reduction in the intensity of controls by one point (i.e., the abolition of one restriction) leads to a decrease in corruption by 0.11 points. This amounts to, e.g., the difference in the index of corruption between Australia and Switzerland, or between Austria and Portugal over the period 1999-2002.

Column (2) employs the index of capital account restrictions as the dependent variable instead. Again, the Hausman test rejects the random effects model, so we include a dummy for each country. As covariates, we employed variables usually included in regressions trying to explain restrictions on the capital account, focusing on three groups of variables: The first group contains variables accounting for the political system, and political as well as economic crises. We, second, include variables measuring the degree of development, suggested by Brune et al. (2001), and, finally, economic variables. Again, we initially included each group of variables separately, and kept those that have been significant at the $10 \%$ level at least.

As can be seen, a larger population, lower monetary growth and higher GDP growth lead to fewer restrictions, at the $1 \%$ level of significance. Smaller countries derive more benefits from integration and are therefore more likely to have open capital accounts. Capital flight is more attractive with higher money growth, since domestic interest rates tend to fall. Countries with lower rates of economic growth might feel the need to liberalize in order to attract foreign capital.

Smaller gross domestic savings reduce restrictions at the $1 \%$ level of significance. Arguably, restrictions become more attractive when savings are high. In this specification, left-wing governments, trade openness and GDP per capita do not significantly influence restrictions, even though they had been significant in the preliminary regressions. ${ }^{28}$

Turning to our variable of interest, the index of corruption is significant at the 5\% level. Its coefficient shows that an increase in corruption by one point leads to 0.16 points more restrictions on the capital account. This is well in line with Proposition 2.

In summary, our results are in line with the theoretical model introduced above. Corruption and capital account restrictions do indeed affect each other mutually.

We proceed with investigating this mutual relationship in more detail and test for Granger-causality between these two variables.

To test for the direction of relationship between controls and corruption we use a dynamic model. Causality is defined in the sense of Granger (1969). That is, a (stationary) variable $x$ is (Granger-)causing a (stationary) variable $y$ if past values of $x$ help to explain $y$, once the past influence of $y$ has been accounted for.

If we have $N$ cross-sectional units observed over $T$ time periods, the model is:

$$
y_{i, t}=\sum_{j=1}^{m} a_{j} y_{i, t-j}+\sum_{j=1}^{m} \beta_{j} x_{i, t-j}+\alpha_{i}+u_{i, t},
$$

(2006) finding that voter turnout in Mississippi is higher in corrupt than in non-corrupt counties supports Rose-Ackerman's hypothesis that corruption is punished in democratic election. Kunicová and RoseAckerman (2005) provide evidence that proportional representation systems are associated with higher levels of corrupt political rent-seeking. We cannot test this given the fixed effects setup employed here.

${ }^{28}$ In addition to these variables, we included an index of political instability constructed in Dreher (2006). The index turned out to be completely insignificant. Note that our results are only partly in line with those of Brune et al. (2001). For a sample of developing countries, they find in particular that richer and more open countries had more open capital accounts. However, Brune et al. focus on a substantially different sample and do not account for corruption, as we do. 
Table 2 Granger-causality tests on corruption and capital account restrictions (panel data, 80 countries, 1984-2002, OLS)

\begin{tabular}{|c|c|c|c|c|c|c|c|}
\hline & \multicolumn{3}{|c|}{ Corruption } & & \multicolumn{3}{|c|}{ Restrictions } \\
\hline & (1) & (2) & (3) & & (4) & (5) & (6) \\
\hline Restrictions (t-1) & $-0.10^{* *}$ & 0.01 & -0.03 & Corruption (t-1) & $0.16^{* * *}$ & 0.02 & 0.10 \\
\hline Restrictions (t-2) & & -0.06 & -0.09 & Corruption (t-2) & & $0.24^{* * *}$ & 0.04 \\
\hline Restrictions (t-3) & & & 0.15 & Corruption (t-3) & & & $0.35^{* * *}$ \\
\hline Corruption (t-1) & $0.55^{* * *}$ & $0.68^{* * *}$ & $0.49^{* * *}$ & Restrictions (t-1) & $0.75^{* * *}$ & $0.72^{* * *}$ & $0.57^{* * *}$ \\
\hline Corruption (t-2) & & $-0.45^{* * *}$ & $-0.45^{* * *}$ & Restrictions (t-2) & & $-0.19^{* * *}$ & $-0.20^{* *}$ \\
\hline Corruption (t-3) & & & -0.09 & Restrictions (t-3) & & & 0.12 \\
\hline $\begin{array}{l}\mathrm{p} \text {-value for (joint) } \\
\text { significance } \\
\text { of restrictions }\end{array}$ & 0.01 & 0.45 & 0.23 & & 0.00 & 0.00 & 0.00 \\
\hline $\begin{array}{l}\text { p-value for (joint) } \\
\text { significance } \\
\text { of corruption }\end{array}$ & 0.00 & 0.00 & 0.00 & & 0.00 & 0.00 & 0.00 \\
\hline
\end{tabular}

Notes:

***: significant at the $1 \%$ level

**: significant at the $5 \%$ level

All variables are averages over three years

where $i=1, \ldots, N$ and $t=1, \ldots, T$. The parameters are denoted $a_{j}$ and $\beta_{j}$, the maximal lag length is $m, \alpha_{i}$ represents unobserved individual effects and $u_{i, t}$ is an independently and identically distributed stochastic error.

Given that Granger causality tests are based on the assumption that the series are stationary, we have to test this assumption beforehand. ${ }^{29}$ We employ the unit root test proposed by Maddala and Wu (1999) for panel data. ${ }^{30}$ Specifically, the Maddala-Wu test consists in first testing the unit root for each cross-sectional unit separately. We determine the optimal number of lags to be included using the $\mathrm{Ng}$ and Perron (1995) sequential t-test on the highest order lag coefficient. Based on the p-values of the individual unit root tests, the overall Maddala-Wu test statistic is calculated. Note, however, that the time dimension of our panel consists of seven observations only and is thus rather short. Consequently, we cannot expect the panel unit root test to provide reliable evidence. The results are suggestive rather than definitive. Still, the hypothesis of a unit root is rejected at the $1 \%$ level for corruption and capital account restrictions alike.

Table 2 proceeds with the test for Granger-causality and shows mixed results. As can be seen, corruption is significantly affected by capital account restrictions when one lag of both variables is included, but not for lag length two and three. Corruption affects restrictions at the $1 \%$ level of significance, to the contrary, independent of the number of lags included.

In order to account for potential endogeneity we apply the system GMM estimator as suggested by Arellano and Bond (1991), Arellano and Bover (1995) and Blundell and Bond

\footnotetext{
${ }^{29}$ We thank a referee for pointing this out.

${ }^{30}$ We employ the Maddala-Wu test rather than other unit root tests as it is applicable to our unbalanced panel data set.
} 
Table 3 Granger-causality tests on corruption and capital account restrictions (panel data, 80 countries, 1984-2002, GMM)

\begin{tabular}{|c|c|c|c|c|c|c|c|}
\hline & \multicolumn{3}{|c|}{ Corruption } & & \multicolumn{3}{|c|}{ Restrictions } \\
\hline & (1) & (2) & (3) & & (4) & (5) & (6) \\
\hline Restrictions (t-1) & $-0.18^{* * *}$ & 0.02 & -0.07 & Corruption (t-1) & $0.19^{* *}$ & $0.17^{*}$ & 0.04 \\
\hline Restrictions (t-2) & & $-0.13^{* *}$ & -0.11 & Corruption (t-2) & & 0.01 & -0.17 \\
\hline Restrictions (t-3) & & & -0.002 & Corruption (t-3) & & & 0.12 \\
\hline Corruption (t-1) & $0.79^{* * *}$ & $0.82^{* * *}$ & $0.84^{* * *}$ & Restrictions (t-1) & $0.89^{* * *}$ & $0.95^{* * *}$ & $0.95^{* * *}$ \\
\hline Corruption (t-2) & & $-0.27^{* * *}$ & $-0.43^{* * *}$ & Restrictions ( $\mathrm{t}-2$ ) & & $-0.17^{* *}$ & $-0.27^{* *}$ \\
\hline Corruption (t-3) & & & 0.20 & Restrictions (t-3) & & & 0.10 \\
\hline $\begin{array}{l}\text { Arrelano-Bond test } \\
\text { (p-value) }\end{array}$ & 0.02 & 0.10 & 0.84 & & 0.03 & 0.12 & 0.70 \\
\hline $\begin{array}{l}\text { Sargan-Hansen test } \\
\text { (p-value) }\end{array}$ & 0.13 & 0.25 & 0.21 & & 0.07 & 0.13 & 0.14 \\
\hline $\begin{array}{l}\text { p-value for (joint) } \\
\text { significance } \\
\text { of restrictions }\end{array}$ & 0.00 & 0.02 & 0.04 & & 0.00 & 0.00 & 0.00 \\
\hline $\begin{array}{l}\text { p-value for (joint) } \\
\text { significance } \\
\text { of corruption }\end{array}$ & 0.00 & 0.00 & 0.00 & & 0.00 & 0.15 & 0.59 \\
\hline
\end{tabular}

Notes:

***: significant at the $1 \%$ level

**: significant at the $5 \%$ level

All variables are averages over three years

(1998). Results are based on the two-step estimator implemented by Roodman (2007) in Stata, including Windmeijer's (2005) finite sample correction.

Table 3 presents the results. The null hypothesis that restrictions have no effect on corruption can be rejected for lag length one and two. For lag length one, the same is true if we use restrictions as the dependent variable and test for the influence of corruption. We conclude that taking corruption and capital account restrictions as exogenous determinants of each other is at least questionable. Simultaneity may be an issue even if the Granger test rejects causality (see Granger 1969; Engle et al. 1983). Given the results of our tests, we do not pursue the issue further.

Table 4 proceeds by estimating corruption and capital account restrictions simultaneously, which amounts to a direct test of our theoretical model. We employ two-stage least squares (2SLS), which allows for the inclusion of endogenous regressors that are dependent variables from other equations in the system. We replicate the regressions of Table 1, but instrument corruption and restrictions with their respective explanatory variables.

As can be seen in columns 1 and 2 of Table 4, the results are similar to those presented above. Democracy reduces corruption at the $1 \%$ level of significance. The results regarding capital account restrictions are very similar to those reported previously - both qualitatively and quantitatively. According to the results, restrictions on the capital account breed corruption, whereas corruption leads to more restrictions, with coefficients significant at the $10 \%$ level of significance. Compared to the individual estimations, the coefficients show a somewhat stronger impact. A reduction in the intensity of controls by one point (i.e., the abolition of one restriction) leads to a decrease in corruption by 0.17 points. An increase in 
Table 4 Determinants of corruption and capital account restrictions (panel data, 78 countries, 1984-2002, 2SLS, fixed effects)

\begin{tabular}{|c|c|c|c|c|}
\hline & $\begin{array}{l}\text { (1) } \\
\text { Capital account } \\
\text { restrictions }\end{array}$ & $\begin{array}{l}\text { (2) } \\
\text { Corruption } \\
\text { (ICRG) }\end{array}$ & $\begin{array}{l}\text { (3) } \\
\text { Capital account } \\
\text { restrictions }\end{array}$ & $\begin{array}{l}\text { (4) } \\
\text { Corruption } \\
\text { (TI) }\end{array}$ \\
\hline Corruption (ICRG) & $\begin{array}{l}0.517 \\
(1.92)^{*}\end{array}$ & & & \\
\hline Corruption (TI) & & & $\begin{array}{l}0.740 \\
(2.26)^{* *}\end{array}$ & \\
\hline Left governments, dummy & $\begin{array}{l}-0.011 \\
(0.06)\end{array}$ & & $\begin{array}{l}-0.583 \\
(1.21)\end{array}$ & \\
\hline $\ln$ (gdp per capita) & $\begin{array}{l}-0.409 \\
(1.48)\end{array}$ & & $\begin{array}{l}-0.396 \\
(0.74)\end{array}$ & \\
\hline $\ln ($ population) & $\begin{array}{l}-1.425 \\
(3.76)^{* * *}\end{array}$ & & $\begin{array}{l}-2.402 \\
(3.28)^{* * *}\end{array}$ & \\
\hline Openness & $\begin{array}{l}-0.005 \\
(1.57)\end{array}$ & & $\begin{array}{l}0.006 \\
(0.71)\end{array}$ & \\
\hline Monetary growth & $\begin{array}{l}0.0003 \\
(2.88)^{* * *}\end{array}$ & & $\begin{array}{l}-0.000 \\
(0.06)\end{array}$ & \\
\hline Gross domestic savings & $\begin{array}{l}0.033 \\
(3.99)^{* * *}\end{array}$ & & $\begin{array}{l}0.037 \\
(1.71)^{*}\end{array}$ & \\
\hline gdp growth & $\begin{array}{l}-0.027 \\
(2.26)^{* *}\end{array}$ & & $\begin{array}{l}-0.027 \\
(1.06)\end{array}$ & \\
\hline Capital account restrictions & & $\begin{array}{l}0.170 \\
(1.83)^{*}\end{array}$ & & $\begin{array}{l}0.548 \\
(2.28)^{* *}\end{array}$ \\
\hline Index of democracy & & $\begin{array}{l}-0.069 \\
(4.02)^{* * *}\end{array}$ & & $\begin{array}{l}0.004 \\
(0.09)\end{array}$ \\
\hline Constant & $\begin{array}{l}36.592 \\
(4.98)^{* * *}\end{array}$ & $\begin{array}{l}-4.087 \\
(10.41)^{* * *}\end{array}$ & $\begin{array}{l}44.771 \\
(4.09)^{* * *}\end{array}$ & $\begin{array}{l}-4.784 \\
(4.79)^{* * *}\end{array}$ \\
\hline Observations & 404 & 404 & 124 & 124 \\
\hline Number of countries & 78 & 78 & 27 & 27 \\
\hline First stage F-statistic & 15.72 & 11.75 & 7.16 & 4.54 \\
\hline Sargan-Hansen test (p-value) & & 0.63 & & 0.03 \\
\hline
\end{tabular}

Notes: Instruments for corruption (capital account restrictions) are the covariates used in Table 1. t-statistics in parentheses:

*** : significant at the $1 \%$ level

**: significant at the $5 \%$ level

$*$ : significant at the $10 \%$ level

All variables are averages over three years

corruption by one point leads to 0.52 points more restrictions on the capital account. According to the results, the Sargan-Hansen test does not reject the overidentifying restrictions at conventional levels of significance in the corruption equation. ${ }^{31}$ The Anderson canonical

\footnotetext{
${ }^{31}$ Note that there are no overidentifying restrictions in the capital restrictions equation.
} 
correlations LR statistic and the Cragg-Donald chi-sq statistic-both tests of whether the equation is identified-also do not reject the specifications at conventional levels of significance. F-tests on the joint significance of the instruments in the first stage regressions (conditional on all exogenous variables in the system) show that they are good predictors of corruption and, respectively, capital account restrictions, significant at the $1 \%$ level. The F-statistics also exceed the critical rule-of thumb value of 10 (Staiger and Stock 1997).

In columns 3 and 4 we test for the robustness of our results to using an alternative index of corruption. The index is provided by Transparency International (2003) and ranges from zero to 10 . We rescaled the index so that higher values represent more corruption. In terms of statistical significance, the results are even stronger than before: At the 5\% level capital account restrictions rise with more corruption, while corruption increases with more restrictions. Note, however, that the sample is reduced to 124 observations from 27 countries and the Sargan-Hansen test is borderline. The results are thus merely suggestive. ${ }^{32}$

As another test for robustness we replicate the analysis employing the GMM system estimator (as described above) in Table 5. Again, columns 1 and 2 focus on the ICRG index of corruption. As the Arellano-Bond test of second-order autocorrelation rejects the null hypothesis of no autocorrelation, we cannot use lags of order two as instruments. However, lags of order three and further are still valid as instruments. ${ }^{33}$ The resulting specification uses 34 instruments; the Sargan-Hansen test does not reject the specifications at conventional levels of significance. While all control variables except for the lagged dependent variable are completely insignificant, the impact of corruption remains significant at the 5\% level, with a coefficient somewhat smaller than in the 2SLS results of Table 4 (see column 1). However, as column 2 shows restrictions do not significantly affect corruption when the GMM estimator is employed.

Columns 3 and 4 again replicate the analysis employing the corruption index of Transparency International instead of the ICRG index. As can be seen, all variables (except for the lagged dependent variables and monetary growth) are completely insignificant, including our variables of interest. However, the sample is reduced to about one-third as compared to columns 1 and 2, so the results are again rather suggestive.

To summarize, our empirical results are well in line with the theoretical model introduced in Sect. 2. We find support for our two propositions: Capital account restrictions significantly increase the level of corruption, while corruption significantly increases the degree of capital account restrictions in turn. In our regressions, the respective effects of corruption and capital account restrictions on each other somewhat increase, once taking the endogeneity into account. However, the impact of capital account restrictions on corruption is not robust to the method of estimation: it is not significant at conventional levels when estimated with GMM.

\section{Conclusion}

We provide a formal model illustrating the mutual relationship between corruption and capital account restrictions: while higher corruption leads to stricter restrictions, stricter restrictions lead to more corruption. Thus, corruption and restrictions reinforce each other. Using

\footnotetext{
${ }^{32}$ Note that we also replicated the results employing Tobit rather than OLS to take account of the bounded nature of our indices. All results are unchanged. They are available on request.

${ }^{33}$ See Bond and Meghir (1994).
} 
Table 5 Determinants of corruption and capital account restrictions (panel data, 1984-2002, GMM)

\begin{tabular}{|c|c|c|c|c|}
\hline & $\begin{array}{l}\text { (1) } \\
\text { Capital account } \\
\text { restrictions }\end{array}$ & $\begin{array}{l}\text { (2) } \\
\text { Corruption } \\
\text { (ICRG) }\end{array}$ & $\begin{array}{l}\text { (3) } \\
\text { Capital account } \\
\text { restrictions }\end{array}$ & $\begin{array}{l}\text { (4) } \\
\text { Corruption } \\
\text { (TI) }\end{array}$ \\
\hline Lagged dependent variable & $\begin{array}{l}0.714 \\
(6.55)^{* * *}\end{array}$ & $\begin{array}{l}0.451 \\
(2.67)^{* * *}\end{array}$ & $\begin{array}{l}0.922 \\
(3.53)^{* * *}\end{array}$ & $\begin{array}{l}0.317 \\
(1.79)^{*}\end{array}$ \\
\hline Capital account restrictions & & $\begin{array}{l}0.038 \\
(0.50)\end{array}$ & & $\begin{array}{l}-0.236 \\
(1.28)\end{array}$ \\
\hline Corruption (ICRG) & $\begin{array}{l}0.340 \\
(2.04)^{* *}\end{array}$ & & & \\
\hline Corruption (TI) & & & $\begin{array}{l}-0.220 \\
(0.76)\end{array}$ & \\
\hline Left governments, dummy & $\begin{array}{l}0.148 \\
(1.10)\end{array}$ & & $\begin{array}{l}0.007 \\
(0.03)\end{array}$ & \\
\hline $\ln ($ gdp per capita $)$ & $\begin{array}{l}-0.059 \\
(0.64)\end{array}$ & & $\begin{array}{l}-0.401 \\
(1.20)\end{array}$ & \\
\hline $\ln$ (population) & $\begin{array}{l}-0.021 \\
(0.23)\end{array}$ & & $\begin{array}{l}-0.026 \\
(0.18)\end{array}$ & \\
\hline Openness & $\begin{array}{l}-0.007 \\
(1.05)\end{array}$ & & $\begin{array}{l}0.004 \\
(0.50)\end{array}$ & \\
\hline Monetary growth & $\begin{array}{l}0.000 \\
(0.51)\end{array}$ & & $\begin{array}{l}0.001 \\
(3.23)^{* * *}\end{array}$ & \\
\hline Gross domestic savings & $\begin{array}{l}0.013 \\
(1.23)\end{array}$ & & $\begin{array}{l}0.009 \\
(0.70)\end{array}$ & \\
\hline gdp growth & $\begin{array}{l}-0.008 \\
(0.52)\end{array}$ & & $\begin{array}{l}-0.000 \\
(0.01)\end{array}$ & \\
\hline Index of democracy & & $\begin{array}{l}-0.013 \\
(0.39)\end{array}$ & & $\begin{array}{l}-0.111 \\
(1.26)\end{array}$ \\
\hline Constant & $\begin{array}{l}2.443 \\
(1.34)\end{array}$ & $\begin{array}{l}-1.779 \\
(3.44)^{* * *}\end{array}$ & $\begin{array}{l}2.232 \\
(0.51)\end{array}$ & $\begin{array}{l}-0.737 \\
(0.68)\end{array}$ \\
\hline Observations & 337 & 350 & 98 & 105 \\
\hline Number of countries & 74 & 75 & 26 & 28 \\
\hline Sargan-Hansen test (p-value) & 0.13 & 0.27 & 0.74 & 0.22 \\
\hline Arrelano-Bond test (p-value) & 0.01 & 0.04 & 0.14 & 0.99 \\
\hline
\end{tabular}

Notes: t-statistics in parentheses:

***: significant at the $1 \%$ level

**: significant at the $5 \%$ level

*: significant at the $10 \%$ level

All variables are averages over three years

a panel of 80 countries, we find empirical support for the relationship hypothesized in our model. Corruption and capital account restrictions are jointly determined. In our model, corrupt countries are more likely to impose capital controls because corruption reduces a 
government's ability to collect tax revenue. If controls exist, however, individuals try to mitigate the burden by offering bribes, thereby increasing corruption.

These results bear important policy implications. They suggest that governments hoping to increase tax revenue by introducing capital controls must take account of the negative equilibrium effects of increased corruption and evasion. Introducing or tightening controls on capital require a careful weighing of the pros and cons of such controls. Individuals often quickly find ways to circumvent new restrictions so that the net effect on the tax revenue may well turn out to be small - and may even be overcompensated by the negative effects of higher corruption. Analogously, attempts to increase the revenue by increasing tax rates on capital flows may equally raise the level of evasion and avoidance. The possibility of a vicious circle in which the mutual reinforcement of corruption and controls involves a spiral of increasing restrictiveness of controls and corruption exists. In equilibrium, the levels of corruption and restrictions might end up being destructively high.

Moreover, if capital account restrictions become stricter, the level of resources used for lobbying and rent-seeking activities of investor groups (beyond corruption) in order to achieve easier restrictions will also rise; similarly, rent-seeking activities of public servants to achieve stricter controls will likely be intensified when the level of corruption rises. Heckelman (2000, 2007) and Horgos and Zimmermann (2009) provide recent evidence that interest group activity significantly decreases the rates of growth and inflation. ${ }^{34}$ Hence, the welfare costs of the restrictions-corruption spiral could well be even higher than described in our model.

In light of the ongoing worldwide financial crisis, calls for stricter regulations abound. Our study advises treating those calls with caution. Introducing additional capital controls to fight the effects of the crises (or globalization, as also frequently demanded), might produce more harm than good, as controls increase corruption, tax evasion and other forms of rentseeking.

Clearly, our results do not imply that zero restrictions will always be optimal. They do imply, however, that one must carefully consider the adverse effects of restrictions beyond what seems to be the immediate economic effects.

Acknowledgements We thank Hans Gersbach, Thomas Herzfeld, Joseph Joyce, Johann Graf Lambsdorff, Miltos Makris, Pierre-Guillaume Méon, Felix Mühe, Michael Rimmler, Bibhas Saha, William F. Shughart, two anonymous referees, and participants at the 2004 Annual Meeting of the European Public Choice Society in Berlin and the 64th Congress of the International Institute of Public Finance (IIPF) in Maastricht (2008) for helpful comments on an earlier draft.

Open Access This article is distributed under the terms of the Creative Commons Attribution Noncommercial License which permits any noncommercial use, distribution, and reproduction in any medium, provided the original author(s) and source are credited.

\footnotetext{
${ }^{34}$ See also the seminal work of Olson (1982), as well as North (1983), Tang and Hedley (1998), or Sui (2009). Shughart et al. (2003) report evidence from the US states that rent-seeking activities also cause the distribution of income to become more unequal.
} 


\section{Appendix A}

Table A.1 Definitions and data sources

\begin{tabular}{|c|c|c|}
\hline Variable & Source & Definition \\
\hline $\begin{array}{l}\text { Corruption } \\
\text { (ICRG) }\end{array}$ & $\begin{array}{l}\text { International Country Risk } \\
\text { Guide }\end{array}$ & $\begin{array}{l}\text { Range } 0 \text { (no corruption) to } 6 \text { (highest } \\
\text { corruption). }\end{array}$ \\
\hline Corruption (TI) & Transparency International & $\begin{array}{l}\text { Range } 0 \text { (no corruption) to } 10 \text { (highest } \\
\text { corruption). }\end{array}$ \\
\hline $\begin{array}{l}\text { Capital account } \\
\text { restrictions }\end{array}$ & $\begin{array}{l}\text { Grilli and Milesi-Ferretti } \\
\text { (1995), updated }\end{array}$ & Range 0 (no restrictions) to 4 (fully restricted). \\
\hline $\begin{array}{l}\text { Index of } \\
\text { democracy }\end{array}$ & Marshall and Jaggers (2000) & $\begin{array}{l}\text { Measures the general openness of political } \\
\text { institutions }(0=\text { low, } 10=\text { high democracy } \\
\text { score). }\end{array}$ \\
\hline $\begin{array}{l}\text { Government } \\
\text { fractionalization }\end{array}$ & Beck et al. (2001) & $\begin{array}{l}\text { The probability that two deputies picked at } \\
\text { random from among the government parties } \\
\text { will be of different parties. }\end{array}$ \\
\hline $\begin{array}{l}\text { Opposition } \\
\text { fractionalization }\end{array}$ & Beck et al. (2001) & $\begin{array}{l}\text { The probability that two deputies picked at } \\
\text { random from among the opposition parties } \\
\text { will be of different parties. }\end{array}$ \\
\hline $\begin{array}{l}\text { Competitive } \\
\text { nomination }\end{array}$ & Banks (2002) & $\begin{array}{l}\text { Index: (3) Competitive, (2) Partly } \\
\text { Competitive, (1) Essentially Non-Competitive, } \\
\text { (0) No Legislature }\end{array}$ \\
\hline $\begin{array}{l}\text { Fixed exchange } \\
\text { rate }\end{array}$ & IMF (various years) & $\begin{array}{l}\text { Dummy is equal to zero if a currency is freely } \\
\text { fluctuating, and } 1 \text { otherwise. }\end{array}$ \\
\hline $\begin{array}{l}\text { Share of } \\
\text { protestants }\end{array}$ & Treisman (2000), CIA (2002) & Protestant population in $\%$. \\
\hline Openness & World Bank (2006) & $\begin{array}{l}\text { The sum of exports and imports of goods and } \\
\text { services measured as a share of GDP. }\end{array}$ \\
\hline $\begin{array}{l}\text { Government } \\
\text { revenue }\end{array}$ & World Bank (2006) & $\begin{array}{l}\text { General government final consumption } \\
\text { expenditure in } \% \text { of GDP. }\end{array}$ \\
\hline $\ln ($ gdp per capita) & World Bank (2006) & $\begin{array}{l}\text { GDP divided by midyear population (in } \\
\text { constant US \$). }\end{array}$ \\
\hline $\begin{array}{l}\text { Illiteracy rate }(\% \\
\text { of people ages } 15 \\
\text { and above })\end{array}$ & World Bank (2006) & $\begin{array}{l}\text { The fraction of people ages } 15 \text { and above who } \\
\text { cannot, with understanding, read and write a } \\
\text { short, simple statement on their everyday life. }\end{array}$ \\
\hline $\begin{array}{l}\text { Socialist } \\
\text { governments }\end{array}$ & Beck et al. (2001) & $\begin{array}{l}\text { Chief Executive's party is defined as } \\
\text { communist, socialist, social democratic, or } \\
\text { left-wing. }\end{array}$ \\
\hline $\begin{array}{l}\text { Political } \\
\text { instability }\end{array}$ & Dreher (2006) & $\begin{array}{l}\text { Index constructed with principal components } \\
\text { analysis. The weights obtained for the } \\
\text { components are } 0.08 \text { (assassination), } 0.1 \\
\text { (strikes), } 0.25 \text { (guerrilla warfare), } 0.15 \text { (crisis), } \\
0.16 \text { (riots) and } 0.27 \text { (revolutions). }\end{array}$ \\
\hline
\end{tabular}


Table A.1 (Continued)

\begin{tabular}{|c|c|c|}
\hline Variable & Source & Definition \\
\hline Banking crises & Glick and Hutchison (2005) & $\begin{array}{l}\text { Dummy takes value of one if a crisis occurred } \\
\text { that year, zero otherwise. }\end{array}$ \\
\hline Currency crises & $\begin{array}{l}\text { Glick and Hutchison (2005), } \\
\text { Capiro and Klingebiel (2003) }\end{array}$ & $\begin{array}{l}\text { Dummy takes value of one if a crisis occurred } \\
\text { that year, zero otherwise. }\end{array}$ \\
\hline Monetary growth & World Bank (2006) & Money and quasi money growth (annual \%). \\
\hline $\begin{array}{l}\text { Gross domestic } \\
\text { savings }\end{array}$ & World Bank (2006) & $\begin{array}{l}\text { Gross domestic savings are calculated as GDP } \\
\text { less final consumption expenditure. }\end{array}$ \\
\hline $\ln ($ population) & World Bank (2006) & $\begin{array}{l}\text { All residents regardless of legal status or } \\
\text { citizenship. }\end{array}$ \\
\hline gdp growth & World Bank (2006) & $\begin{array}{l}\text { Annual percentage growth rate of GDP at } \\
\text { market prices based on constant local currency. }\end{array}$ \\
\hline
\end{tabular}

\section{Appendix B}

Table B.1 Descriptive statistics

\begin{tabular}{|c|c|c|c|c|}
\hline & Mean & St.dev. & Min & $\operatorname{Max}$ \\
\hline Corruption (ICRG) & 2.81 & 1.02 & 0.00 & 6.00 \\
\hline Corruption (TI) & 3.43 & 1.70 & 0.00 & 7.45 \\
\hline Capital account restrictions & 2.43 & 1.16 & 0.00 & 4.00 \\
\hline Index of democracy & 3.85 & 3.74 & 0.00 & 10.00 \\
\hline Government fractionalization & 0.17 & 0.26 & 0.00 & 1.00 \\
\hline Opposition fractionalization & 0.47 & 0.30 & 0.00 & 1.00 \\
\hline Competitive nomination & 1.38 & 0.65 & 0.00 & 3.00 \\
\hline Fixed exchange rate & 0.59 & 0.46 & 0.00 & 1.00 \\
\hline Share of protestants & 0.40 & 2.68 & 0.00 & 31.64 \\
\hline Openness & 67.35 & 36.38 & 1.60 & 264.79 \\
\hline Government revenue & 21.91 & 9.72 & 2.69 & 53.79 \\
\hline $\ln ($ gdp per capita $)$ & 7.08 & 1.12 & 4.73 & 9.48 \\
\hline $\ln$ (population) & 16.13 & 1.61 & 11.97 & 20.95 \\
\hline Illiteracy rate ( $\%$ of people ages 15 and above) & 29.13 & 22.77 & 0.20 & 91.08 \\
\hline Socialist governments & 0.31 & 0.45 & 0.00 & 1.00 \\
\hline Political instability & 0.25 & 0.40 & 0.00 & 4.21 \\
\hline Monetary growth & 72.30 & 420.82 & -10.52 & 7630.39 \\
\hline Gross domestic savings & 16.98 & 12.09 & -39.51 & 60.72 \\
\hline gdp growth & 2.80 & 4.01 & -20.05 & 14.98 \\
\hline
\end{tabular}




\section{Appendix C}

Table C.1 Countries included in the estimations

\begin{tabular}{|c|c|c|}
\hline Albania & Guyana & Papua New Guinea \\
\hline Algeria & Haiti & Paraguay \\
\hline Argentina & Honduras & Peru \\
\hline Bahrain & Hungary & Philippine \\
\hline Bangladesh & India & Poland \\
\hline Bolivia & Indonesia & Romania \\
\hline Botswana & Iran & Russia \\
\hline Brazil & Jamaica & Saudi Arabia \\
\hline Bulgaria & Jordan & Senegal \\
\hline Cameroon & Kenya & Sierra Leone \\
\hline Chile & Korea, Rep. & Slovak Rep. \\
\hline China & Latvia & South Africa \\
\hline Colombia & Lithuania & Sri Lanka \\
\hline Congo, Dem. Rep. & Madagascar & Syrian Arab Rep. \\
\hline Congo, Rep & Malawi & Tanzania \\
\hline Costa Rica & Malaysia & Thailand \\
\hline Croatia & Mali & Togo \\
\hline Czech Republic & Mexico & Trinidad and Tobago \\
\hline Dominican Republic & Morocco & Tunisia \\
\hline Ecuador & Myanmar & Turkey \\
\hline Egypt & Namibia & Uganda \\
\hline El Salvador & Nicaragua & Ukraine \\
\hline Estonia & Niger & Uruguay \\
\hline Gabon & Nigeria & Venezuela \\
\hline Ghana & Oman & Zambia \\
\hline Guatemala & Pakistan & Zimbabwe \\
\hline Guinea-Bissau & Panama & \\
\hline
\end{tabular}

\section{References}

Ades, A., \& Di Tella, R. (1999). Rents, competition, and corruption. American Economic Review, 89(4), 982-993.

Aidt, T. S., \& Gassebner, M. (2007). Do autocratic states trade less? Cambridge Working Papers in Economics 0742 , University of Cambridge.

Alesina, A., \& Weder, B. (2002). Do corrupt governments receive less foreign aid? The American Economic Review, 92(4), 1126-1137.

Alfaro, L. (2001). Capital controls: a political economy approach. Harvard Business School Working Papers 02-012, Harvard University.

IMF (various years). Annual report on exchange arrangement and exchange restrictions. Washington: International Monetary Fund.

Arellano, M., \& Bond, S. (1991). Some tests of specification for panel data: Monte Carlo evidence and an application to employment equations. Review of Economic Studies, 58, 277-297.

Arellano, M., \& Bover, O. (1995). Another look at the instrumental variable estimation of error-components models. Journal of Econometrics, 68(1), 29-51. 
Asiedu, E., \& Lien, D. (2003). Capital controls and foreign direct investment. World Development, 32(3), 479-490.

Bai, C.-E., \& Wei, S.-J. (2001). The quality of bureaucracy and capital account policies. World Bank working paper series, No. 2575. Washington: World Bank, Development Research Group.

Banks, A. S. (2002). Cross-national time-series data archive. Binghamton: Banner Software.

Bartolini, L., \& Drazen, A. (1997). Capital-account liberalization as a signal. American Economic Review, 87(1), 138-154.

Beck, Th., Demirgüç-Kunt, A., \& Levine, L. (2001). New tools in comparative political economy: The Database of Political Institutions. World Bank Economic Review, 15(1), 165-176.

Becker, G. (1983). A theory of competition among pressure groups for political influence. Quarterly Journal of Economics, 98(3), 371-400.

Bhagwati, J. N. (1982). Directly unproductive, profit-seeking (DUP) activities. Journal of Political Economy, 90(5), 988-1002.

Blundell, R., \& Bond, S. (1998). Initial conditions and moment restrictions in dynamic panel data models. Journal of Econometrics, 87(1), 115-143.

Boehm, F. (2007). Regulatory capture revisited-lessons from economics of corruption. Working Paper, Internet Center for Corruption Research. http://www.icgg.org/.

Bond, S., \& Meghir, C. (1994). Dynamic investment models and the firm's financial policy. Review of Economic Studies, 61(2), 197-222.

Brune, N., Garrett, G., Guisinger, A., \& Sorens, J. (2001). The political economy of capital account liberalization. Paper prepared for the 2001 Annual Meeting of the American Political Science Association, San Francisco.

Büchner, S., Freytag, A., González, L. G., \& Güth, W. (2008). Bribery and public procurement: an experimental study. Public Choice, 137(1-2), 103-117.

Burgess, R., \& Stern, N. (1993). Taxation and development. Journal of Economic Literature, 31(2), 762-830.

Capiro, G., \& Klingebiel, D. (2003). Episodes of systemic and borderline financial crises. Washington: World Bank.

CIA (2002). World factbook. Washington: Central Intelligence Agency (CIA). Internet: http://www.odci.gov/ cia/publications/factbook/ downloaded 26 Nov. 2003.

DeLong, B., \& Eichengreen, B. (2002). Between meltdown and moral hazard: the international monetary and financial policies of the Clinton administration. In J. Frankel \& P. Orszag (Eds.), American economic policy in the 1990s (pp. 191-254). Cambridge: MIT Press.

Depken, C. A. II, \& Lafountain, L. (2006). Fiscal consequences of public corruption: empirical evidence from state bond ratings. Public Choice, 126(1), 75-85.

Dooley, M., \& Isard, P. (1980). Capital controls, political risk and deviations from interest-rate parity. Journal of Political Economy, 88, 370-384.

Drabek, Z., \& Payne, W. (2001). The impact of transparency on foreign direct investment. WTO Working Paper ERAD-99-02.

Dreher, A. (2006). Does globalization affect growth? Evidence from a new index of globalization. Applied Economics, 38(10), 1091-1110.

Dreher, A., \& Gassebner, M. (2007). Greasing the wheels of entrepreneurship? The impact of regulations and corruption on firm entry. KOF Working Paper 166. ETH Zurich.

Dreher, A., \& Herzfeld, Th. (2008). The economic costs of corruption: a survey of the empirical evidence. In F. Columbus (Ed.), Economic corruption and its impact. New York: Nova Science.

Dreher, A., Kotsogiannis, C., \& McCorriston, S. (2007). Corruption around the world: evidence from a structural model. Journal of Comparative Economics, 35(3), 443-466.

Duso, T. (2005). Lobbying and regulation in a political economy: Evidence from the US Cellular Industry. Public Choice, 122(2-3), 251-276.

Eaton, J. (1987). Public debt guarantees and private capital flight. World Bank Economic Review, 1(3), 377395.

Edwards, S. (1999). How effective are capital controls? NBER Working Paper 7413.

Eigen, P. (2008). Removing a roadblock to development. Innovations, 3(2), 19-33.

El-Shagi, M. (2005a). A legal crime: capital controls as an act of corruption. Mimeo, University of Mannheim.

El-Shagi, M. (2005b). Korruption und Kapitalverkehrskontrollen. In M. El-Shagi \& G. Rübel (Eds.), Aspekte der internationalen Ökonomie_Festschrift für Jürgen Schröder zum (Vol. 65, pp. 173-186). Wiesbaden: Geburtstag.

El-Shagi, M. (2006). Der Lockruf der Kapitalverkehrskontrollen. In Hanns-Martin-Schleyer-Stiftung: Globale Wirtschaft-nationale Verantwortung: Wege aus dem Druckkessel: Forschungsergebnisse im Überblick, Berlin (pp. 70-71). 
El-Shagi, M. (2007). Capital controls and corruption: A case of reversed causality? In: Proceedings of the CLAS (forthcoming).

Engle, R. F., Hendry, D. F., \& Richards, J.-F. (1983). Exogeneity. Econometrica, 51(2), 277-304.

Friehe, T. (2008). Correlated payoffs in the inspection game: some theory and an application to corruption. Public Choice, 137(1-2), 127-143.

Gerring, J., \& Thacker, S. (2004). Political institutions and governance: pluralism versus centralism. British Journal of Political Science, 34(2), 295-303.

Giavazzi, F., \& Pagano, M. (1988). Capital controls in the EMS. In D. E. Fair \& C. de Boissieu (Eds.), International monetary and financial integration: the European dimension (pp. 261-289). Dordrecht: Kluwer Academic.

Glick, R., \& Hutchison, M. M. (2005). Capital controls and exchange rate instability in developing economies. Journal of International Money and Finance, 24(3), 387-412.

Goel, R. K., \& Nelson, M. A. (1998). Corruption and government size: a disaggregated analysis. Public Choice, 97(1-2), 107-120.

Granger, C. W. J. (1969). Testing for causality and feedback. Econometrica, 37(3), 424-438.

Grilli, V., \& Milesi-Ferretti, G. M. (1995). Economic effects and structural determinants of capital controls. IMF Staff Papers, 42(3), 517-551.

Gruben, W. C., \& McLeod, D. (2001). Capital account liberalization and disinflation in the 1990s. Federal Reserve Bank of Dallas CLAE Working Paper 0101.

Hasseldine, D. J., \& Bebbington, K. J. (1991). Blending economic deterrence and fiscal psychology models in the design of responses to tax evasion: The New Zealand experience. Journal of Economic Psychology, 12, 299-324.

Heckelman, J. C. (2000). Consistent estimates of the impact of special interest groups on economic growth. Public Choice, 104(3-4), 319-327.

Heckelman, J. C. (2007). Explaining the rain: the rise and decline of nations after 25 years. Southern Economic Review, 74, 18-33.

Horgos, D., \& Zimmermann, K. W. (2009). Interest groups and economic performance: some new evidence. Public Choice, 138(3-4), 301-315.

Jain, A. K. (2001). Corruption: a review. Journal of Economic Surveys, 15(1), 71-121.

Karahan, G., Coates, R. M., \& Shughart, W. F. II (2006). Corrupt political jurisdictions and voter participation. Public Choice, 126(1), 87-106.

Knack, S., \& Keefer, P. (1995). Institutions and economic performance: cross-country tests using alternative institutional measures. Economics and Politics, 7(3), 207-227.

Krueger, A. O. (1974). The political economy of the rent-seeking society. American Economic Review, 64(3), 291-303.

Krueger, A. O. (1993). Virtuous and vicious circles in economic development. American Economic Review, 83(2), 351-355.

Kunicová, J., \& Rose-Ackerman, S. (2005). Electoral rules and constitutional structures as constraints on corruption. British Journal of Political Science, 35(4), 573-606.

Lambsdorff, J. Graf (2002). Corruption and rent-seeking. Public Choice, 113(1-2), 97-125.

Lambsdorff, J. Graf (2006). Causes and consequences of corruption: what do we know from a cross-section of countries. In S. Rose-Ackerman (Ed.), International handbook on the economics of corruption (pp. 3-51). Cheltenham: Edward Elgar.

Lambsdorff, J. Graf (2007). The institutional economics of corruption and reform: theory, evidence and policy. Cambridge: Cambridge University Press.

Lederman, D., Loayaza, N., \& Reis Soares, R. (2001). Accountability and corruption: political institutions matter. University of Chicago and World Bank.

Maddala, G. S., \& Wu, S. (1999). A comparative study of unit root tests with panel data and new simple test. Oxford Bulletin of Economics and Statistics, 61, 631-652.

Marshall, M. G., \& Jaggers, K. (2000). Polity IV Project: political regime characteristics and transitions, 1800-2000. Center for International Development and Conflict Management, University of Maryland, College Park, M.D. Internet: http://www.cidcm.umd.edu/inscr/polity/, downloaded 17 Oct. 2003.

Mbaku, J. M. (1991). Military expenditures and bureaucratic competition for rents. Public Choice, 71(2), 19-31.

Mbaku, J. M. (1996). Bureaucratic corruption in Africa: the futility of cleanups. Cato Journal, 16(1), 99-118.

Méon, P.-G., \& Sekkat, K. (2005). Does corruption grease or sand the wheels of growth? Public Choice, 122(1-2), 69-97.

Méon, P.-G., \& Weill, L. (2006). Is corruption an efficient grease? Mimeo.

Milesi-Ferretti, G. M. (1998). Why capital controls? Theory and evidence. In S. Eijffinger \& H. Huizinga (Eds.), Positive political economy: theory and evidence (pp. 217-247). Cambridge: Cambridge University Press. 
Neely, C. J. (1999). An introduction to capital controls. Federal Reserve Bank of St. Louis Review, 81(6), 13-30.

Nell, M. \& Lambsdorff, J. Graf (2007). Fighting corruption with asymmetric penalities and leniency. CeGE Discussion Paper 59. Center for Globalization and Europeanization of the Economy, Georg-AugustUniversity Göttingen.

$\mathrm{Ng}, \mathrm{S}$., \& Perron, P. (1995). Unit root tests in ARMA models with data-dependent methods for the selection of the truncation lag. Journal of the American Statistical Association, 90, 268-281.

North, D. C. (1983). A theory of economic change. Science, 219, 163-164.

North, D. C. (1994). Economic performance through time. American Economic Review, 84(3), 359-363.

Olson, M. (1982). The rise and decline of nations, economic growth, stagflation, and social rigidities. New Haven: Yale University Press.

Peltzman, S. (1976). Toward a more general theory of regulation. Journal of Law and Economics, 19, 211240.

Posner, R. (1974). Theories of economic regulation. Bell Journal of Economics and Management Science, 5 , $335-358$.

Roine, J. (2006). The political economics of not paying taxes. Public Choice, 126(1), 107-134.

Roodman, D. (2007): xtabond2: Stata module to extend xtabond dynamic panel data estimator. Center for Global Development, Washington, DC Retrieved January 9, 2008, from http://econpapers.repec.org/ software/bocbocode/s435901.htm.

Rose-Ackerman, S. (1978). Corruption: a study in political economy. New York: Academic Press.

Rose-Ackerman, S. (1997). The political economy of corruption. In K. A. Elliot (Ed.), Corruption and the Global Economy (pp. 31-60). Washington: Institute for International Economics.

Rose-Ackerman, S. (1999). Corruption and government: causes, consequences, and reform. Cambridge: Cambridge University Press.

Rowley, C. K. (2006). Terrorist attacks on Western civilization. Public Choice, 128, 1-6.

Schumpeter, J. A. (1942). Capitalism, socialism and democracy. New York: Harper.

Shleifer, A., \& Vishny, W. (1993). Corruption. Quarterly Journal of Economics, 108(3), 599-617.

Shughart, W. F. II (2006). An analytical history of terrorism, 1945-2000. Public Choice, 128(1-2), 7-39.

Shughart, W. F. II, \& Tollison, R. D. (2005). Public Choice in the new century. Public Choice, 124(1), 1-18.

Shughart, W. F. II, Tollison, R. D., \& Yan, Z. (2003). Rent seeking into the income distribution. Kyklos, 56(4), $441-455$.

Smarzynska, B. K., \& Wei, S.-J. (2000). Corruption and composition of foreign direct investment. NBER Working Paper 7969.

Staiger, D., \& Stock, J. H. (1997). Instrumental variables regression with weak instruments. Econometrica, 65(3), 557-586.

Stigler, G. (1971). The theory of economic regulation. Bell Journal of Economics and Management Science, 2(1), 3-21.

Stockman, A. C., \& Hernandez, A. D. (1988). Exchange controls, capital controls, and international financial markets. American Economic Review, 78(3), 362-374.

Sui, Y. (2009). Rent-seeking contests with private values and resale. Public Choice, 138(34), 409-422.

Tang, E. W. Y., \& Hedley, R. A. (1998). Distributional coalitions, state strength, and economic growth: toward a comprehensive theory of economic development. Public Choice, 96(3-4), 295-323.

Transparency International (2003). Corruption perceptions index. Berlin: Transparency International. Internet: http://www.transparency.org/surveys/index.html\#cpi, downloaded 16 Oct. 2003.

Treisman, D. (2000). The causes of corruption: a cross-national study. Journal of Public Economics, 76, 399-457.

Weber Abramo, C. (2008). How much do perceptions of corruption really tell us? Economics: The Open-Access, Open-Assessment E-Journal, 2, 2008-3. http://www.economics-ejournal.org/economics/ journalarticles/2008-3.

Wei, S.-J. (2000). How taxing is corruption on international investors? Review of Economics and Statistics, LXXXII, 1-11.

Wheeler, D., \& Mody, A. (1992). International investment location decision: the case of US firms. Journal of International Economics, 33, 57-76.

Windmeijer, F. (2005). A finite sample correction for the variance of linear efficient two-step GMM estimators. Journal of Econometrics, 126(1), 25-51.

World Bank (2006). World Development Indicators (WDI), CD-Rom. Washington, DC.

World Bank (2008). Homepage of the World Bank Group, Area Anticorruption. Washington, DC. Internet: http://go.worldbank.org/K6AEEPROC0, downloaded 27 August 2008.

World Bank Institute (2007). Worldwide governance indicators: 1996-2006. World Bank Group. Washington, DC. http://www.govindicators.org. 